\title{
ELECTRIC PROPERTIES OF LITHIUM-CONDUCTING SOLID ELECTROLYTE CERAMICS
}

\author{
T. Šalkus ${ }^{\text {a }}$, A. Dindune ${ }^{\text {b }}$, Z. Kanepe ${ }^{\text {b }}$, J. Ronis ${ }^{\text {b }}$, A. Kežionis ${ }^{\text {a }}$, E. Kazakevičius ${ }^{\text {a }}$, \\ L.J. Gauckler ${ }^{\mathrm{c}}$, U.P. Mucke ${ }^{\mathrm{c}}$, and A.F. Orliukas ${ }^{\mathrm{a}}$

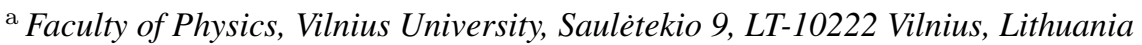 \\ E-mail: tomas.salkus@ff.vu.lt \\ ${ }^{\mathrm{b}}$ Institute of Inorganic Chemistry at the Riga Technical University, Miera 34, LV-2169 Salaspils, Latvia \\ ${ }^{\mathrm{c}}$ Department of Materials, ETH Hönggerberg, Wolfgang-Pauli-Str. 10, CH-8093 Zürich, Switzerland
}

Received 28 November 2006

\begin{abstract}
The high temperature solid electrolyte $\mathrm{Li}_{1.3} \square_{1.7} \mathrm{Sc}_{0.3} \mathrm{Ce}_{1.7}\left(\mathrm{PO}_{4}\right)_{3}$ (where $\square$ is an absence of $\mathrm{Li}^{+}$) compound was synthesized by a solid state reaction and studied by X-ray diffraction at room temperature. At room temperature the investigated compound belong to monoclinic symmetry (space group $\mathrm{P} 2_{1} / \mathrm{n}$ ) with four formula units in the lattice. The ceramic samples were sintered at $923 \mathrm{~K}$ for $1 \mathrm{~h}$. The surface of the ceramics was investigated by SEM and the chemical composition was tested by EDX. Complex impedance spectroscopy was performed in the frequency range from $10^{-1}$ to $1.2 \cdot 10^{9} \mathrm{~Hz}$ in temperature range from 500 to $700 \mathrm{~K}$. Three relaxation dispersions were found. The dispersions are related to the fast $\mathrm{Li}^{+}$ion transport in the grain boundaries and grains of the ceramics and to the processes at the Pt electrode-electrolyte interface.
\end{abstract}

Keywords: ionic conductivity, permittivity, relaxation dispersion, synthesis, ceramic, sintering

PACS: $61.10 . \mathrm{Nz}, 66.30 . \mathrm{Hs}, 81.05 . \mathrm{Je}, 82.45 . \mathrm{Yz}$

\section{Introduction}

Highly ion-conducting solids are promising materials for development of high energy batteries [1] and $\mathrm{CO}_{2}$ sensors [2]. $\quad \mathrm{LiM}_{2}\left(\mathrm{PO}_{4}\right)_{3}$ (where $\mathrm{M}=\mathrm{Ge}, \mathrm{Zr}$, Ti) compounds with $\mathrm{Li}^{+}$ion transport were extensively studied because of their high ionic conductivity and chemical stability [3-5]. Esaka et al. reported that the addition of $\mathrm{Li}^{+}$ions in $\mathrm{YPO}_{4}$ compound caused the appearance of the ionic conductivity of $\mathrm{Li}_{3 x} \mathrm{Y}_{1-x} \mathrm{PO}_{4}$ solid solution [6]. Orlova et al. synthesized $\mathrm{LiCe}_{2}\left(\mathrm{PO}_{4}\right)_{3}$ and $\mathrm{Li}_{3} \mathrm{Ce}_{1.5}\left(\mathrm{PO}_{4}\right)_{3}$ compounds by the liquid-phase method and studied by X-ray diffraction at room and elevated temperatures [7]. These compounds have typical $\mathrm{CePO}_{4}$ monazite-type structure and belong to monoclinic symmetry (space group $\mathrm{P} 22_{1} / \mathrm{n}$ ) with four formula units in the lattice [7]. The authors [8] reported that monazite crystals synthesized by hydrothermal method at temperature of 373 and $473 \mathrm{~K}$ belong to hexagonal and monoclinic symmetry respectively. The XPS indicate that the phosphorus exists completely in the form of $\mathrm{PO}_{4}^{3-}$ and cerium exists as $\mathrm{Ce}(\mathrm{III})$ with no $\mathrm{Ce}(\mathrm{IV})$ in all investigated crystals [8].
It was shown that conductivity of $\mathrm{Li}_{3} \mathrm{Sc}_{2}\left(\mathrm{PO}_{4}\right)_{3}$ was increased by partial isomorphous substitution of three valence $\mathrm{Sc}^{3+}$ by $\mathrm{B}^{3+}[9]$. High $\mathrm{Li}^{+}$ion conductivity, their low activation energy stimulate the search and investigation of new $\mathrm{Li}^{+}$conducting solid electrolyte materials.

In the present work we have performed the partial substitution of $\mathrm{Ce}^{3+}$ by $\mathrm{Sc}^{3+}$ in the system $\mathrm{Li}_{2} \mathrm{O}-\mathrm{Ce}_{2} \mathrm{O}_{3}-\mathrm{P}_{2} \mathrm{O}_{5}$ (stoichiometric compound is $\left.\mathrm{Li}_{3} \mathrm{Ce}_{2}\left(\mathrm{PO}_{4}\right)_{3}\right)$. We report the conditions for the synthesis of the $\mathrm{Li}_{1.3} \square_{1.7} \mathrm{Sc}_{0.3} \mathrm{Ce}_{1.7}\left(\mathrm{PO}_{4}\right)_{3}$ powder, sintering of the ceramic samples, and the results of the structure investigation of the compound. The electrical properties of the ceramics have been investigated in the frequency range from $10^{-1}$ to $1.2 \cdot 10^{9} \mathrm{~Hz}$ in the temperature range from 500 to $700 \mathrm{~K}$.

\section{Experimental}

The powder of $\mathrm{Li}_{1.3} \square_{1.7} \mathrm{Sc}_{0.3} \mathrm{Ce}_{1.7}\left(\mathrm{PO}_{4}\right)_{3}$ was synthesized from mixture of $\mathrm{CeO}_{2}, \mathrm{Li}_{2} \mathrm{CO}_{3}(\mathrm{pu}-$ rity $99.999 \%$ ), $\mathrm{Sc}_{2} \mathrm{O}_{3}\left(99.99 \%\right.$ ), and $\mathrm{NH}_{4} \mathrm{H}_{2} \mathrm{PO}_{4}$ (extra pure) by solid state reaction. The mixture was milled as emulsion with ethyl alcohol in a planetary mill with 
one milling ball of $52 \mathrm{~mm}$ in diameter and then heated at $723 \mathrm{~K}$ for $3 \mathrm{~h}$. Thereafter the mixture was milled, heated at $1093 \mathrm{~K}$ for $1 \mathrm{~h}$ (in such a system at the temperatures above $773 \mathrm{~K}$ a transition of $\mathrm{Ce}^{4+}$ to $\mathrm{Ce}^{3+}$ takes place), milled again, and heated at $1093 \mathrm{~K}$ for $3 \mathrm{~h}$. Finally, the mixture was milled for $8 \mathrm{~h}$ and dried at temperature $393 \mathrm{~K}$ for $24 \mathrm{~h}$. The chemical analysis has shown that the synthesized compound has an absence of $\mathrm{Li}^{+} \square=1.7$.

The structure parameters were obtained at room temperature from the X-ray powder diffraction patterns recorded with a step of $1^{\circ} \mathrm{min}^{-1}$ in the region $2 \Theta=6 . .80^{\circ}$ using $\mathrm{Cu} \mathrm{K}_{\alpha 1}$ radiation.

The powder was uniaxially cold pressed at $300 \mathrm{MPa}$. The sintering of the ceramics was conducted in air at temperature $T=923 \mathrm{~K}$ for $1 \mathrm{~h}$.

The surface of the ceramics was investigated by SEM (Leo 1530). For the SEM investigation the surface of the ceramic sample was polished using suspension with $1 \mu \mathrm{m}$ diamond particles and thermally etched for $1.5 \mathrm{~h}$ at $873 \mathrm{~K}$ with $10 \mathrm{~K} / \mathrm{min}$ heating and cooling rates. The average grain size of the ceramic samples was estimated from SEM image using the program LINCE which is based on the intercept method [10]. Noran Vantage EDX detector was used to record EDX spectra.

Complex conductivity $\tilde{\sigma}=\sigma^{\prime}+\mathrm{i} \sigma^{\prime \prime}$, complex impedance $\tilde{Z}=Z^{\prime}+\mathrm{i} Z^{\prime \prime}$, and complex dielectric permittivity $\tilde{\varepsilon}=\varepsilon^{\prime}+\mathrm{i} \varepsilon^{\prime \prime}$ were measured while cooling the sample from 700 down to $500 \mathrm{~K}$. In the frequency range from $10^{-1}$ to $10^{5} \mathrm{~Hz}$ the impedance measurements were conducted by impedance measurement unit (IM6, Zahner Electric) by two electrode method and the temperature was stabilized by Eurotherm. The measurements in a frequency range from $10^{6}$ to $1.2 \cdot 10^{9} \mathrm{~Hz}$ were performed by coaxial impedance spectrometer set-up [11]. Pt paste was used to form electrodes on the ceramic samples. The measurements were carried out in air.
Table 1. X-ray powder diffraction data for $\mathrm{Li}_{1.3} \square_{1.7} \mathrm{Sc}_{0.3} \mathrm{Ce}_{1.7}\left(\mathrm{PO}_{4}\right)_{3}$ compound at room temperature.

\begin{tabular}{cccc}
\hline $2 \Theta,^{\circ}$ & $d, \AA$ & $h k l$ & $I / I_{0}, \%$ \\
\hline 17.02 & 5.21 & -101 & 14 \\
18.41 & 4.82 & 110 & 7 \\
18.90 & 4.69 & 011 & 17 \\
21.22 & 4.18 & -111 & 31 \\
21.60 & 4.111 & 101 & 14 \\
25.08 & 3.548 & 111 & 16 \\
25.32 & 3.515 & 020 & 17 \\
26.92 & 3.309 & 200 & 66 \\
28.75 & 3.103 & 120 & 100 \\
29.83 & 2.9928 & 210 & 14 \\
30.16 & 2.9608 & -211 & 6 \\
31.12 & 2.8716 & $012 ;-112$ & 74 \\
34.42 & 2.6035 & -202 & 17 \\
36.78 & 2.4416 & -212 & 16 \\
37.30 & 2.4088 & 220 & 6 \\
41.08 & 2.1955 & 031 & 17 \\
42.10 & 2.1446 & -311 & 29 \\
42.34 & 2.1330 & 221 & 18 \\
46.00 & 1.9714 & 212 & 20 \\
46.70 & 1.9435 & 301 & 6 \\
47.80 & 1.9013 & -231 & 11 \\
48.44 & 1.8777 & -132 & 23 \\
50.63 & 1.8015 & 023 & 8 \\
51.72 & 1.7660 & -132 & 14 \\
52.40 & 1.7447 & 132 & 17 \\
52.80 & 1.7324 & -223 & 8 \\
53.90 & 1.6996 & $-401 ; 140$ & 6 \\
55.55 & 1.6530 & 400 & 3 \\
\hline
\end{tabular}

\section{Results and discussion}

The results of the $\mathrm{X}$-ray diffraction study have shown that $\mathrm{Li}_{1.3} \square_{1.7} \mathrm{Sc}_{0.3} \mathrm{Ce}_{1.7}\left(\mathrm{PO}_{4}\right)_{3}$ powder is mainly single phase material. The corresponding $\mathrm{X}$-ray powder diffraction pattern at room temperature is presented in Fig. 1. The X-ray powder diffraction data are listed in Table 1. The $\mathrm{Li}_{1.3} \square_{1.7} \mathrm{Sc}_{0.3} \mathrm{Ce}_{1.7}\left(\mathrm{PO}_{4}\right)_{3}$ compound belongs to the monoclinic symmetry (space group $\mathrm{P} 22_{1} / \mathrm{n}$ ) with four formula units in the lattice. The lattice parameters were found to be $a=6.8001$ (13) ,

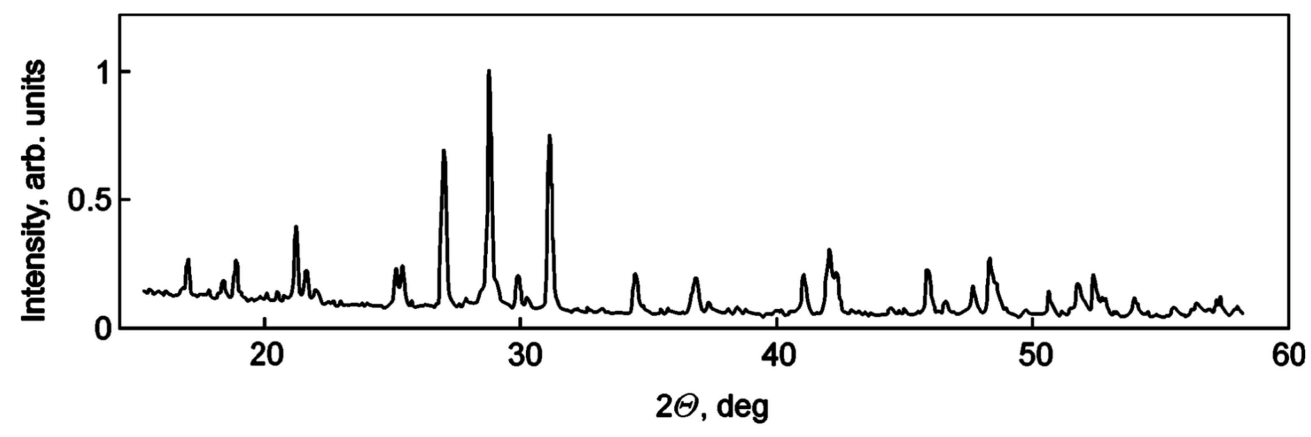

Fig. 1. X-ray diffraction pattern of the $\mathrm{Li}_{1.3} \square_{1.7} \mathrm{Sc}_{0.3} \mathrm{Ce}_{1.7}\left(\mathrm{PO}_{4}\right)_{3}$ powder. 


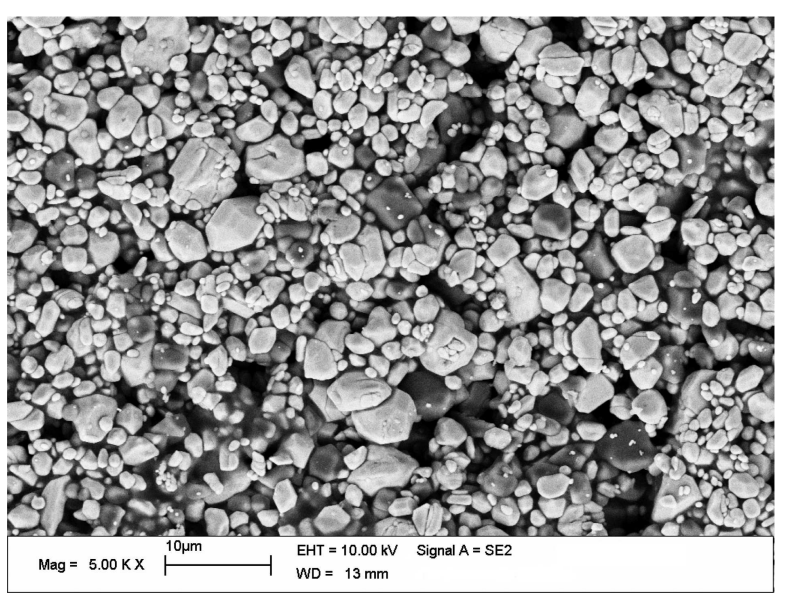

Fig. 2. SEM image of the $\mathrm{Li}_{1.3} \square_{1.7} \mathrm{Sc}_{0.3} \mathrm{Ce}_{1.7}\left(\mathrm{PO}_{4}\right)_{3}$ ceramic surface.

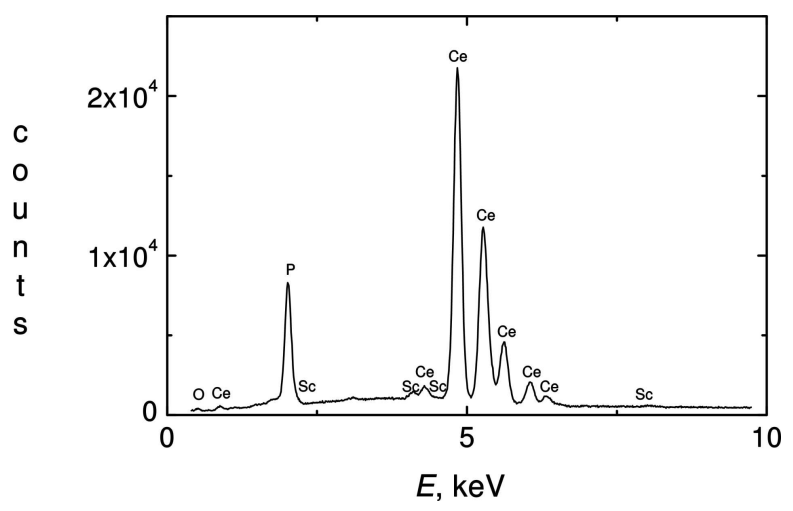

Fig. 3. EDX spectra of the $\mathrm{Li}_{1.3} \square_{1.7} \mathrm{Sc}_{0.3} \mathrm{Ce}_{1.7}\left(\mathrm{PO}_{4}\right)_{3}$ ceramic grain.

$b=7.0294(14) \AA, c=6.4737(14) \AA, \beta=103.468(21)^{\circ}$, and the unit cell volume is $V=300.93 \AA^{3}$. The theoretical density of the compound was found to be $d_{\mathrm{X} \text {-ray }}=4.01 \mathrm{~g} / \mathrm{cm}^{3}$. The average grain size of the obtained powder was calculated from X-ray powder diffraction pattern according to Scherer formula:

$$
D=\frac{K \lambda}{(\Delta 2 \Theta) \cos \Theta_{0}},
$$

where $D$ is a particle size, a constant $K=0.9$, the wavelength of the $\mathrm{Cu} \mathrm{K}_{\alpha 1}$ radiation $\lambda=1.5418 \AA$, $\Theta_{0}$ is an angle of peak intensity, $\Delta 2 \Theta$ is a width of peak at half of intensity. The average grain size of $\mathrm{Li}_{1.3} \square_{1.7} \mathrm{Sc}_{0.3} \mathrm{Ce}_{1.7}\left(\mathrm{PO}_{4}\right)_{3}$ was $0.41 \mu \mathrm{m}$.

The density of the ceramics was found to be $81 \%$ of the theoretical density of the compound. SEM image of the studied ceramic sample is presented in Fig. 2. The average grain size of the ceramics determined was $2.2 \mu \mathrm{m}$. A grain intersection to grain size factor of 1.56 was used [10]. EDX spectrum has shown the sample to be free of foreign elements (Fig. 3).

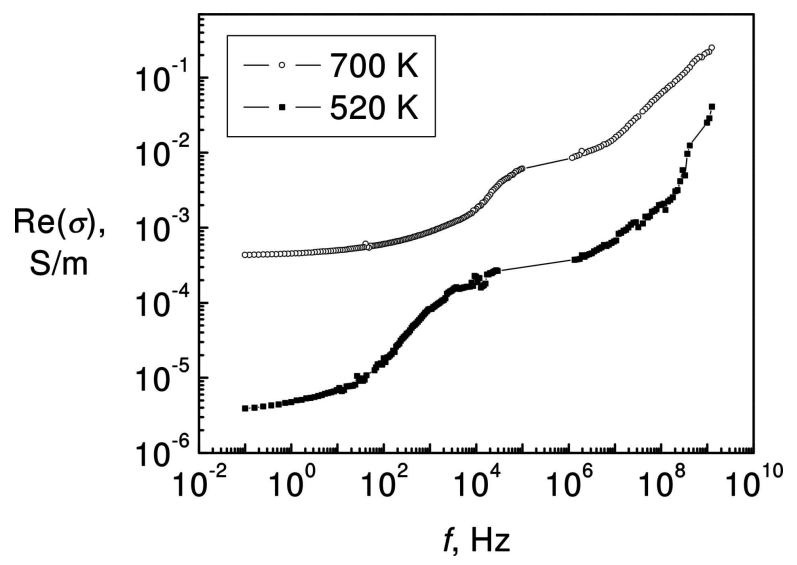

Fig. 4. Frequency dependences of the real part of conductivity of $\mathrm{Li}_{1.3} \square_{1.7} \mathrm{Sc}_{0.3} \mathrm{Ce}_{1.7}\left(\mathrm{PO}_{4}\right)_{3}$ ceramics at different temperatures.

The impedance investigation of the ionic conductivity in the wide frequency and in the broad temperature ranges has an advantage because it allows separating all three charge carrier transport processes in grains, grain boundaries of the ceramics, and in the electrode-solid electrolyte interface [12]. The characteristic frequency dependences of the real part of $\tilde{\sigma}$ of $\mathrm{Li}_{1.3} \square_{1.7} \mathrm{Sc}_{0.3} \mathrm{Ce}_{1.7}\left(\mathrm{PO}_{4}\right)_{3}$ ceramics at different temperatures are shown in Fig. 4. Three dispersion regions were found in $\sigma^{\prime}$ spectra. All dispersion regions shift towards higher frequencies with increase of the temperature. The low frequency dispersion ranges of $10^{2}-10^{4} \mathrm{~Hz}$ at temperature $T=520 \mathrm{~K}$ and $10^{4}-10^{5} \mathrm{~Hz}$ at temperature $T=700 \mathrm{~K}$ are related to the blocking Pt electrodes. The temperature dependences of total $\left(\sigma_{\mathrm{t}}\right)$ and grain $\left(\sigma_{\mathrm{g}}\right)$ conductivities of $\mathrm{Li}_{1.3} \square_{1.7} \mathrm{Sc}_{0.3} \mathrm{Ce}_{1.7}\left(\mathrm{PO}_{4}\right)_{3}$ ceramics were derived from complex plots of $\tilde{\sigma}(f)$ at different temperatures. The characteristic complex conductivity plots of the ceramic sample are shown in Fig. 5. Higher frequency part of the obtained spectra may be attributed to the relaxation in grains, while lower frequency part corresponds to grain boundary processes as in a wide range of other solid electrolyte ceramics [13-16]. $\sigma_{\mathrm{t}}$ and $\sigma_{\mathrm{g}}$ are indicated with arrows in this graph. At $650 \mathrm{~K}$ the values of total and grain conductivities of the investigated ceramics were found to be $\sigma_{\mathrm{t}}=8.59 \cdot 10^{-4} \mathrm{~S} / \mathrm{m}$ and $\sigma_{\mathrm{g}}=1.95 \cdot 10^{-3} \mathrm{~S} / \mathrm{m}$ respectively. The temperature dependences of $\sigma_{\mathrm{t}}$ and $\sigma_{\mathrm{g}}$ of the ceramic sample are shown in Fig. 6. The activation energies of $\sigma_{\mathrm{t}}$ and $\sigma_{\mathrm{g}}$ were found from the slopes of the Arrhenius plots. The activation energy of total conductivity is $\Delta E_{\mathrm{t}}=$ $1.34 \mathrm{eV}$ and the activation energy of grain conductivity is $\Delta E_{\mathrm{g}}=0.73 \mathrm{eV}$.

The temperature dependences of the real part of dielectric permittivity $\varepsilon^{\prime}$ and dielectric losses $\tan \delta$ 


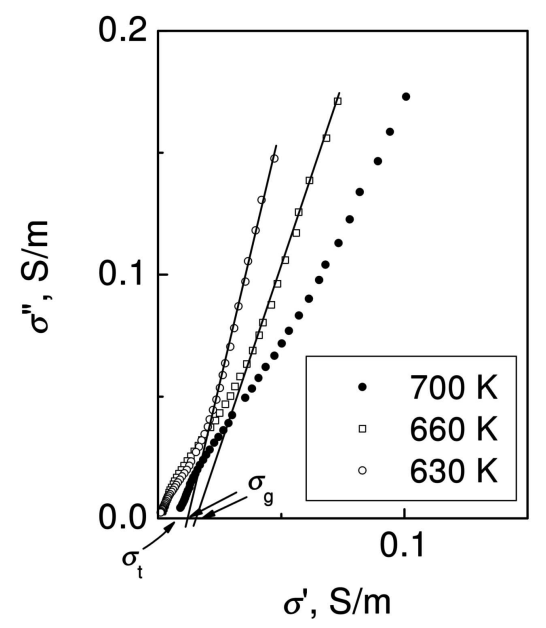

Fig. 5. Complex plane plots of conductivity of $\mathrm{Li}_{1.3} \square_{1.7} \mathrm{Sc}_{0.3} \mathrm{Ce}_{1.7}\left(\mathrm{PO}_{4}\right)_{3}$ ceramics at different temperatures.

were investigated at a frequency of $1 \mathrm{GHz}$. This frequency is higher than Maxwell relaxation frequency $f_{\mathrm{M}}=\sigma_{\mathrm{g}} /\left(\varepsilon^{\prime} \varepsilon_{0}\right)$ (where $\varepsilon_{0}=8.85 \cdot 10^{-12} \mathrm{~F} / \mathrm{m}$ is dielectric constant of the vacuum). At $550 \mathrm{~K}$ temperature the $\omega_{\mathrm{M}}$ of the ceramics was found to be 38.7 MHz. The temperature dependences of $\varepsilon^{\prime}$ and $\tan \delta$ of $\mathrm{Li}_{1.3} \square_{1.7} \mathrm{Sc}_{0.3} \mathrm{Ce}_{1.7}\left(\mathrm{PO}_{4}\right)_{3}$ ceramics are shown in Fig. 7. At $550 \mathrm{~K} \varepsilon^{\prime}=6.03$ and $\tan \delta=0.095$. The increase of the values of $\varepsilon^{\prime}$ with temperature of the investigated compound can be caused by contribution of the migration polarization of lithium ions, vibration of lattice, and electronic polarization. The increase of $\tan \delta$ with temperature is related to the contribution of conductivity in the investigated temperature region.

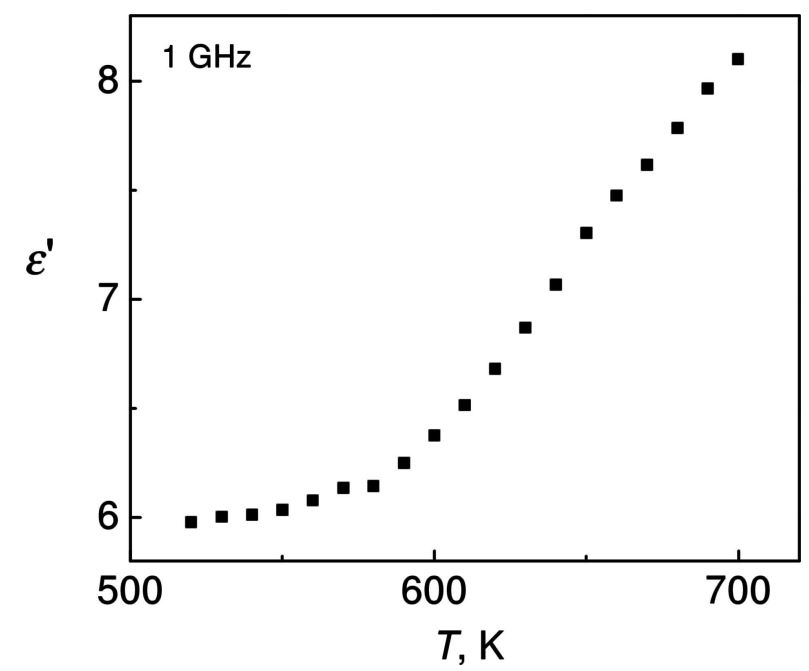

(a)

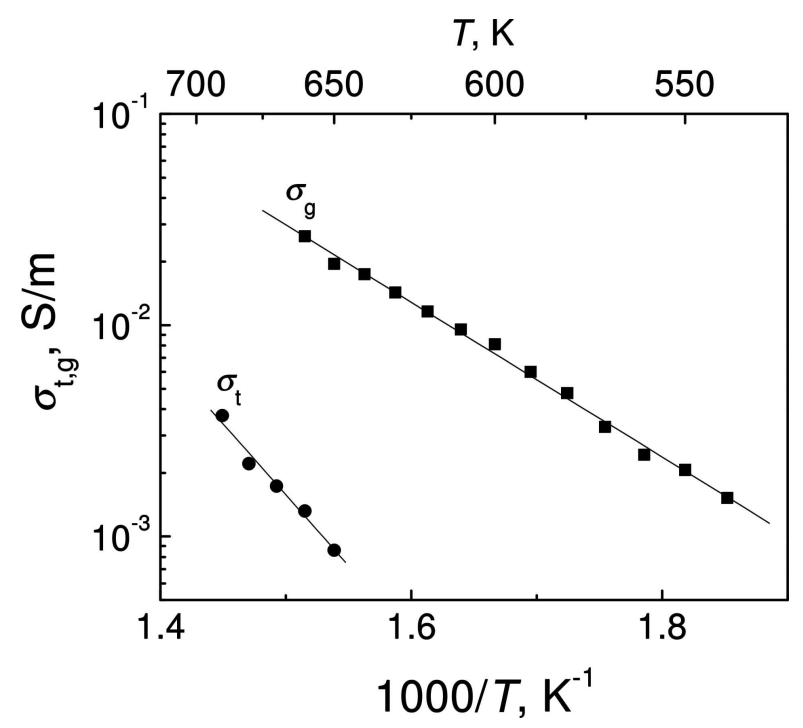

Fig. 6. Temperature dependences of total and grain conductivities of $\mathrm{Li}_{1.3} \square_{1.7} \mathrm{Sc}_{0.3} \mathrm{Ce}_{1.7}\left(\mathrm{PO}_{4}\right)_{3}$ ceramics.

\section{Conclusions}

The solid electrolyte $\mathrm{Li}_{1.3} \square_{1.7} \mathrm{Sc}_{0.3} \mathrm{Ce}_{1.7}\left(\mathrm{PO}_{4}\right)_{3}$ compound has been synthesized by solid phase reactions and studied by the $\mathrm{X}$-ray powder diffraction. The investigated compound belongs to monoclinic symmetry (space group $\mathrm{P} 2{ }_{1} / \mathrm{n}$ ) with 4 formula units in the lattice. The ceramics of $\mathrm{Li}_{1.3} \square_{1.7} \mathrm{Sc}_{0.3} \mathrm{Ce}_{1.7}\left(\mathrm{PO}_{4}\right)_{3}$ were sintered at a temperature of $923 \mathrm{~K}$. The ceramic sample was investigated by complex impedance spectroscopy in the frequency range from $10^{-1}$ to $1.2 \cdot 10^{9} \mathrm{~Hz}$ in the temperature range from 500 to $700 \mathrm{~K}$. Three regions of the relaxation dispersion are related to the blocking electrodes (low frequency range) and ion transport in the grain boundaries and grains of the

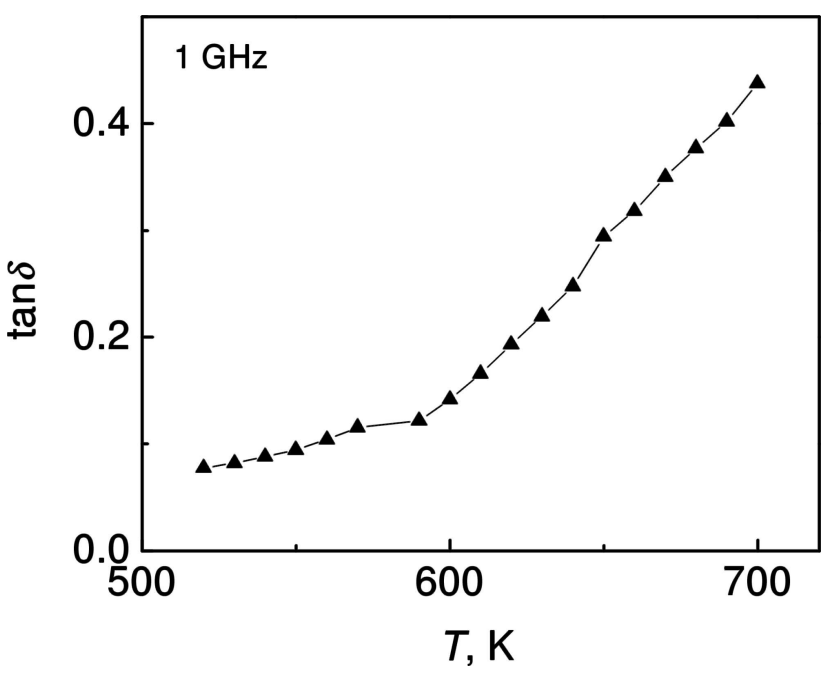

(b)

Fig. 7. Temperature dependences of (a) dielectric permittivity and (b) dielectric losses of $\mathrm{Li}_{1.3} \square_{1.7} \mathrm{Sc}_{0.3} \mathrm{Ce}_{1.7}\left(\mathrm{PO}_{4}\right)_{3}$ ceramics at the $1 \mathrm{Ghz}$ frequency. 
ceramic samples. At $650 \mathrm{~K}, \sigma_{\mathrm{t}}=8.59 \cdot 10^{-4} \mathrm{~S} / \mathrm{m}$ and $\sigma_{\mathrm{g}}=1.95 \cdot 10^{-3} \mathrm{~S} / \mathrm{m}$. The values of $\varepsilon^{\prime}$ at room temperature at $1 \mathrm{GHz}$ frequency are related to the polarization process due to migration of $\mathrm{Li}^{+}$ions, lattice vibrations, and electronic polarization.

\section{References}

[1] M. Broussely, J.P. Planckat, G. Rigobert, D. Virey, and G. Sarre, Lithium-ion batteries for electric vehicles: Performances of 100 Ah cells, J. Power Sources 68, 8-12 (1997).

[2] F. Salam and W. Weppner, Solid-state potentiometric $\mathrm{CO}_{2}$ sensor based on $\mathrm{Li}_{2} \mathrm{CO}_{3}-\mathrm{MgO}$ electrolyte, Ionics 5, 355-359 (1999).

[3] M.A. Subramanian, R. Subramanian, and A. Clearfield, Lithium ion conductors in the system $\mathrm{AB}(\mathrm{IV}) 2\left(\mathrm{PO}_{4}\right)_{3}(\mathrm{~B}=\mathrm{Ti}, \mathrm{Zr}$ and $\mathrm{Hf})$, Solid State Ionics 18-19, 562-569 (1986).

[4] H. Aono, E. Sugimoto, Y. Sadaoka, N. Imanoka, and G. Adachi, Ionic conductivity of solid electrolytes based on lithium titanium phosphate, J. Electrochem. Soc. 137, 1023-1027 (1990).

[5] J.E. Iglesias and C. Pecharromán, Room temperature triclinic modification of NASICON-type $\mathrm{LiZr}_{2}\left(\mathrm{PO}_{4}\right)_{3}$, Solid State Ionics 112, 309-318 (1998).

[6] T. Esaka, Y. Kobayashi, H. Obata, and H. Iwahara, Cation conduction in zircon-type solid solution based on $\mathrm{YPO}_{4}$, Solid State Ionics 34, 287-291 (1989).

[7] A.I. Orlova, D.B. Kitaev, N.G. Kazantsev, S.G. Samoilov, V.S. Kurazhkovskaya, and E.N. Vopilina, Double phosphates of Ce(IV) and some mono- and divalent elements: Synthesis and crystal structure, Radiochemistry 44, 326-331 (2002).
[8] Y. Zhang and H. Guan, Hydrothermal synthesis and characterization of hexagonal and monoclinic $\mathrm{CePO}_{4}$ single-crystal nanowires, J. Crystal Growth 256, 156161 (2003).

[9] A. Dindune, Z. Kanepe, J. Ronis, T. Salkus, A. Kezionis, E. Kazakevicius, and A.F. Orliukas, Characterization and impedance spectroscopy of $\mathrm{Li}_{3} \mathrm{Sc}_{2-x} \mathrm{~B}_{x}\left(\mathrm{PO}_{4}\right)_{3}$ (where $\mathrm{x}=0$-2) solid electrolyte ceramics, Phosphorus Res. Bull. 19, 124-129 (2005).

[10] S.L. dos Santos e Lucato, LINCE (Department of Materials Science, Technical University Darmstadt).

[11] A.F. Orliukas, A. Kezionis, and E. Kazakevicius, Impedance spectroscopy of solid electrolytes in the radio frequency range, Solid State Ionics 176, 20372043 (2005).

[12] Impedance Spectroscopy, ed. J. Ross Macdonald (John Wiley \& Sons, New York, 1987).

[13] R. Sobiestianskas, A. Dindune, Z. Kanepe, J. Ronis, A. Kežionis, E. Kazakevičius, and A. Orliukas, Electrical properties of $\mathrm{Li}_{1+x} \mathrm{Y}_{y} \mathrm{Ti}_{2-y}\left(\mathrm{PO}_{4}\right)_{3}$ (where $x, y=$ $0.3 ; 0.4)$ ceramics at high frequencies, Mater. Sci. Eng. B 76, 184-192 (2000).

[14] W. Bogusz, J.R. Dygas, F. Krok, A. Kezionis, R. Sobiestianskas, E. Kazakevicius, and A. Orliukas, Electrical conductivity dispersion in Co-doped NASICON samples, Phys. Status Solidi A 183, 323-330 (2001).

[15] M. Cretin and P. Fabry, Comparative study of lithium ion conductors in the system $\mathrm{Li}_{1+x} \mathrm{Al}_{x} \mathrm{~A}_{2-x}^{I V}\left(\mathrm{PO}_{4}\right)_{3}$ with $\mathrm{A}^{I V}=\mathrm{Ti}$ or $\mathrm{Ge}$ and $0 \leq x \leq 0.7$ for use as $\mathrm{Li}^{+}$ sensitive membranes, J. Eur. Ceram. Soc. 19, 29312940 (1999).

[16] M. Godickemeier, B. Michel, A. Orliukas, P. Bohac, K. Sasaki, L. Gauckler, H. Heinrich, P. Schwander, G. Kostorz, H. Hofmann, and O. Frei, Effect of intergranular glass films on the electrical conductivity of 3Y-TZP, J. Mater. Res. 9, 1228-1240 (1994). 


\title{
ELEKTRINĖS LIČIO LAIDŽIU઼JU KIETŲJŲ ELEKTROLITŲ SAVYBĖS
}

\author{
T. Šalkus ${ }^{\text {a }}$, A. Dindune ${ }^{\text {b }}$, Z. Kanepe ${ }^{b}$, J. Ronis ${ }^{\text {b }}$, A. Kežionis ${ }^{\text {a }}$, E. Kazakevičius ${ }^{\text {a }}$, L.J. Gauckler ${ }^{\text {c }}$, U.P. Mucke ${ }^{\text {, }}$, \\ A.F. Orliukas ${ }^{a}$ \\ ${ }^{a}$ Vilniaus universitetas, Vilnius, Lietuva \\ ${ }^{\mathrm{b}}$ Rygos technikos universiteto Neorganinès chemijos institutas, Salaspilis, Latvija \\ ${ }^{\mathrm{c}}$ Federalinis technologijos institutas, Ciurichas, Šveicarija
}

\section{Santrauka}

Kietasis $\mathrm{Li}_{1.3} \square_{1.7} \mathrm{Sc}_{0.3} \mathrm{Ce}_{1.7}\left(\mathrm{PO}_{4}\right)_{3}$ (čia $\square$ yra Li ${ }^{+}$trūkumas) elektrolitas buvo susintetintas kietųjų fazių reakcijų metodu. Jo kristalinè struktūra buvo tirta kambario temperatūroje Rentgeno spinduliu difrakcijos nuo milteliu metodu. Nustatyta, kad tirtasis junginys priklauso monoklininei singonijai (erdvinè simetrijos grupè $\mathrm{P} 2_{1} / \mathrm{n}$ ), o jo elementariojoje kristalineje gardeleje yra 4 formuliniai vienetai. Buvo pagamintos šių kietuju elektrolitų keramikos. Keramikų elektrinès savybės buvo tirtos impedanso spektroskopijos metodu, matuojant jų pilnutinę varžą, kompleksinį laidi ir kompleksinę dielektrinę skvarbą $10^{-1}-1,2 \cdot 10^{9} \mathrm{~Hz}$ dažnio elektriniame lauke 500-700 K temperatūros intervale. Tirtose keramikose yra stebimos trys relaksacinio tipo elektriniu parametrų dispersijos, susijusios su blokuojančiais Pt elektrodais, $\mathrm{Li}^{+}$jonu pernaša kristalituose ir tarpkristalitinèse terpèse. Esant $650 \mathrm{~K}$ temperatūrai, bendrasis keramikos laidis $\sigma_{\mathrm{t}}=8,59 \cdot 10^{-4} \mathrm{~S} / \mathrm{m}$ ir kristalitinis laidis $\sigma_{\mathrm{g}}=1,95 \cdot 10^{-3} \mathrm{~S} / \mathrm{m}$. Didejjant temperatūrai, keramikų $\varepsilon^{\prime}$ ir $\tan \delta$ didèja. Keramikų $\varepsilon^{\prime}$ dydị lemia ličio jonų migracinè, joninè tamprioji bei elektroninė poliarizacijos. Matuotų kietųjų elektrolitų dielektrinius nuostolius lemia jų joninio laidumo kaita. 